UDC 339.727.22

DOI 10.33111/iep.eng.2021.34.02

\title{
Imperatives for Global Offshore Business Transformation
}

\author{
YAROSLAVA STOLIARCHUK ${ }^{1}$, \\ ANATOLII PORUCHNYK ${ }^{2}$ \\ HLib TUROLIEV ${ }^{3}$, \\ OLEKSANDR BOHATYROV
}

ABSTRACT. The article is focused on a comprehensive study of global imperatives for offshore business transformation of economic entities, which in recent decades have become a strong framework for increasing their market competitive advantages, manufacturing optimization, "blurring" tax base, and implementing high-pressure tax planning, tax "hybrids" and corporate tax inversions. The article summarizes the methodological approaches to revealing the nature and economic reasons of offshore business based on the arrangement of its key theoretical discourse areas within the framework of international business, management, tax and institutional paradigms. It is emphasized that these paradigms, in line with constant evolving and enriching, reflect the breakthrough trends in international companies, while new scientific schools and fields are accompanied by the active inclusion of business offshoring in the field of research of domestic and foreign scientists. It is proved that the key epistemological feature of the modern theory of offshore business segment is its development within multiparadigmatic framework, which can explain the concept of offshore business in global frame of reference from a dialectical point of view.

It is stated that the direct developers and users of comprehensive offshore tools at all stages of its evolutionary development were the top global countries interested in operating networks of international financial centres and tax havens to use them to gain control over companies and businesses in various global economy sectors. The article indicates the key competitive advantages of offshore business for economic entities - manufacturing optimization, tax optimization, institutional barriers breakdown in course of cross-border movement of goods, manufacturing services and factors, as well as streamlining the accounting system of financial and economic transactions. It is emphasized that the global economy used these means in recent decades to form the new generation of multinational enterprises engaging in production and

\footnotetext{
* This article was translated from its original in Ukrainian.

${ }^{1}$ Stolyarchuk Yaroslava Mykhailivna - Doctor of Economics, Professor of the Department of International Economics of Kyiv National Economic University named after Vadym Hetman. Author of more than 140 scientific publications, including 20 monographs, textbooks and manuals. Sphere of scientific interest: global economic development and its asymmetries, world financial market, international economic integration and transnationalization of national economies, international investment and innovation, world labor market and international labor migration. E-mail: stolyaroslava@ukr.net

${ }^{2}$ Poruchnyk Anatolii Mykhailovych - Doctor of Economics, Professor, Head of the Department of International Economics, Kyiv National Economic University named after Vadym Hetman, Honored Master of Sciences and Engineering of Ukraine. Sphere of scientific interests: international economic integration and global problems of modern age, activities of transnational corporations, world labor market and international labor migration, international investment and innovation activities. E-mail: poruchnyk@kneu.edu.ua

${ }^{3}$ Turoliev Hlib Oleksandrovych - Ph.D. student at the Department of International Economics, Kyiv National Economic University named after Vadym Hetman. Author of more than 20 scientific publications. Sphere of scientific interest: offshore business, international investment, economic globalization, global economic development. E-mail: turolev_gleb@ukr.net

${ }^{4}$ Bohatyrov Oleksandr Ihorovych - Ph.D., Associate Professor of the Department of International Economics of Kyiv National Economic University named after Vadym Hetman. Author of more than 20 scientific publications. Sphere of scientific interest: international marketing, corporate marketing strategies, strategies of foreign banks. E-mail: bogatyrev_77@ukr.net
}

IEP, No. 34 (2021), pp. 23-51

(c) Yaroslava Stoliarchuk, Anatolii Poruchnyk, Hlib Turoliev, Oleksandr Bohatyrov,

2021 «All rights reserved»

ISSN 1811-9832/2021/No. 1 (34) 
services for third parties based on manufacturer-contractor approach and dynamic development in global framework of international networks of foreign affiliates.

The paper substantiates the multichannel nature of modern offshoring of multinational enterprises business through constant influence on its transformation of key imperatives of global economic development: financial and monetary, multinational, institutional and regulatory, social and property, information and communication requirements. It is noted that the common effect of these imperatives has led to the formation of trans-global elite in recent decades and the deep convergence of geographically different offshore territories into a global network of global financial centres joined in organizational, economic, technological, instrumental, institutional and regulatory framework.

KEY WORDS: global economic development, financial globalization, offshore business sector, offshore business, high-pressure tax planning, liberalization of national financial markets, global offshore capital, networking of the global offshore system.

\section{Introduction}

The first quarter of 20th century is marked by significant and vigorous transnationalization processes, radical boosting of the technological basis of social production in terms of industry 4.0, radical structural changes in the system of global industrial relations, dynamic increase of resource capacity, the impact of global financial capital, and regular development of global corporate networks and deeper integration of national economic networks. The joined impact of these processes on the global economy sector is their penetrating into all its subsystems and structural components and radical transformation of the corporate strategies and business models of economic entities, as well as provision of a new business procedures' quality through its fragmentation, network structuring, integration into global value chains, innovation and digitalization.

However, structural changes and quantitative and qualitative parameters of the global business sector is currently most influenced by the systemic processes of offshore business. In their general course, they are aimed at building companies' corporate and non-monopolized economy sectors of their own competitive advantages by internalizing business and financial transactions, full or partial relocation of individual parts of production processes, minimizing transaction costs, management restructuring, etc. According to international practices, within the last decades offshore business became a significant instrument aimed to increase the market competitive advantages of economic entities and boost their production processes, to "blur" the tax base, implement high-pressure tax planning, tax "hybrids" and corporate tax inversions. A strong conflict of state and corporate interests in the tax field propels the states to implement dynamic deoffshorization measures in order to overcome threats to national security in the tax segment.

Among the scientific works containing the most thorough research of issues linked to the disclosure of the theoretical framework of international 
business and fiscal optimization of business operations of multinational enterprises, instruments of offshore business and its consequences, patterns and practice of tax regulation of transfer pricing, national and international tools of offshore operations supervision, it should be noted the papers of the following domestic and foreign scientists: J. Andielik, E. Asen, O. Baula, A. Bereznoi, H. Vamser, J. Venrich, J. Whitaker, J. Voget, J. Henry, M. Desai, K. Dickenson, M. Dissinger, O. Dudar, P. Egger, A. Zablotskyi, H. Zukman, A. Zorome, T. Karkinski, D. Campbell, K. Kiyota, A. Cobham, M. Krishnen, A. Liebman, D. Lipton, V. Makarov, V. Merlo, N. Mudrak, O. Puzakova, E. Redziuk, A. Sachuk, F. Takes, J. Fitchtner, K. Fornell, B. Heifetz, J. Howpt, E. Himskerk, J. Chen, T. Shevlin, N. Shakeson, T. Shepel, P. Jansk, etc. However, foreign and domestic papers insufficiently disclosed the issues of studying the global imperatives of offshore business and the instruments of their influence on the offshore business operations of different nations.

The article is aimed to summarize the theoretical research toolkit of offshore business operations, to reveal the range of factors causing their profound transformational changes within global conditions in line with reasons of instruments of multichannel influence of corporate strategies and multinational enterprises' business models.

\section{Theoretical research toolkit of offshore business operations}

Scientific interest in the issue of offshore international business originated in the depths of classical political economy, theories of international trade, foreign direct and portfolio investment, multinational enterprises, management and the international labour division. Still, only since the beginning of the 2010s the global theoretical discourse of international business singled out the offshore business into a separate and independent direction of the general theory of competitive advantages and factors of production $^{5}$. Having a multiparadigmatic developing framework, the global theory of business offshoring includes the pattern of international business, as well as management, tax and institutional paradigms. The international business paradigm was finalized only in the late 1960s, as a natural reaction of Western scholars to the rapid increase in the post-war period of international investment processes, systematic diversification of financial and economic practices of multinational enterprises and their monopolization of key segments of the global market.

It is worth reminding that the deepest conceptual research of the international business scientific issue is in the papers of R. Aliber, S. Geimer,

\footnotetext{
${ }^{5}$ Zablotskyi A. V. Ofshorynh na svitovomu rynku posluh: teoriia ta perspektyvy rozvytku. Aktualni problemy mizhnarodnykh vidnosyn. 2012. Vyp. 110 (1). S. 17. [In Ukraianian].
} 
P. Buckley, M. Casson, A. Rugman, M. Porter, D. Stopford, A. Chandler ${ }^{6}$, etc. By explaining the foreign production sector mainly through the industrial organization theory and the allocation theory ${ }^{7}$, they fixed the basic theoretical foundations of the study of international companies' foreign operations. At the same time, the scientists relied on the key scientific idea of market competitive advantages of multinational enterprises and the economic benefits obtained from strengthening intra-corporate coordination of financial and economic operations of business entities.

In turn, other Western researchers in the development of international business theoretical discourse made diligent exploration of the issue of monopolistic competition and monopolistic competitive advantages of the multinational enterprises (Ch. Kindlberger) ${ }^{8}$; regularities of cross-border movement of investment capital and transfer of companies' production departments abroad (R. Vernon) ${ }^{9}$; effective combination of managerial capacity and resources of companies (E. Penrose) ${ }^{10}$, etc. We'd like to also mention the scientific achievements in this field of the Reading School of International Business, whose representatives P. Buckley and M. Casson ${ }^{11}$ became the founders of a new area of international economic research internalization processes, which within the last forty years remain the landmark of international business discourse ${ }^{12}$ and are being developed within the framework of theory of firm.

The next life stage of the theoretical discourse of offshore business processes is linked to the development of the eclectic theory of J. Dunning ${ }^{13}$ in the 1970s, which organically integrated on its methodological platform the conceptual approaches of S. Geimer and C. Kindleberger, scientific ideas of the internalization school of P. Buckley and M. Casson and the key foundations of the general methodology of macroeconomic theories of direct investment. At the same time, given the rapid changes of international business networking and fixing of global value chains, since the early 2000s

\footnotetext{
${ }^{6}$ Aliber R. Z. A Theory of Direct Foreign Investment. The International Corporation, Ed. by Ch. Kindlberger, Cam., Mass., MIT Press, 1970. Hymer S. The International Operations of National Firms: A Study of Direct Investment. MIT Press, 1976. Stopfor J. M., Dunning J. H., Haberich K. The world directory of international enterprises. 1980

Pidchosa O. V. Formuvannia teorii transnatsionalnykh korporatsii: bazys ta tendentsii rozvytku. Aktualni problemy mizhnarodnykh vidnosyn. 2010. Vypusk 94. (Chastyna II). S. 257. [In Ukraianian].

${ }^{8}$ Kindleberger C. P. American Business Abroad: Six Lectures on Direct Investment. New Haven: Yale University Press, 1969.

9 Vernon R. International Investment and International Trade in the Product Cycle. Quarterly Journal of Economics. 1966. No. 80. P. 190-207.

${ }_{10}$ Penrose E. T. The Theory of the Growth of the Firm. Oxford: Basil Blackwell, 1963

${ }^{11}$ Casson M. C., Buckley P. J. The Theory of Internationalization. Recent Research on the Multinational Enterprise. London, 1991. Buckley P. J. Multinational Enterprise and the Globalization of Knowledge. New-York: Palgrave Macmillan, 2006.

${ }_{12}^{2}$ Filipenko A. S., Dziuba P. V. Teoriia mizhnarodnoho biznesu: vid narodzhennia do sohodennia. Aktualni problemy mizhnarodnykh vidnosyn. 2019. Vypusk 138. S. 168. [In Ukraianian].

${ }_{13}$ Aliber R. Z. A Theory of Direct Foreign Investment. The International Corporation, Ed. by Ch. Kindlberger, Cam., Mass., MIT Press, 1970. Dunning J. H. Explaining changing patterns of international production: in defence of the electric theory. Oxford bulletin of economics and statistics. 1979. №41 (4). P. 269-295.
} 
the international business pattern is developing within the general framework of the theory of international production fragmentation of $\mathrm{M}$. Porter, R. Jones and G. Kezhkovski ${ }^{14}$; inter-organizational theory of multinational enterprises of S. Ghoshal and K. Bartlett ${ }^{15}$; A. Rugman's ${ }^{16}$ concept of "flagship networking multinational enterprises"; P. Buckley's ${ }^{17}$ theory of the "global factory", etc ${ }^{18}$.

A comprehensive analysis of the management paradigm of the theoretical discourse of offshore business practices suggests that it focuses on process structured methodological approaches to business process management (planning, organization, motivation, control and adjustment) as the basis of their effective business procedures and achievement of strategic and tactical goals. In keeping with this approach, it should be underlined that the birth of the first theories of management in the late 19th century was a natural response of science to the growing needs of the corporate sector to boost profits and reduce operating costs within a limited resource framework and the need for their rational use. Thus, F. Taylor, as one of the founders of the theory of operational management, for the first time introduced into the theoretical discourse the concept of scientific management and a differentiated system of remuneration depending on the quality of their products and production performance. Moreover, we'd like to note the importance of the mathematical approaches developed by F. Taylor to the assessment of personnel production performance, selection and training. This was reflected in his fundamental work "Principles of Scientific Management" ${ }^{19}$ published in 1911 and fixed the key framework of the management paradigm of the theoretical discourse of business offshoring.

Further development of "Taylorism" ideas is found in the theoretical paper of M. Cook, Kh. Ford and W. Shewhart ${ }^{20}$, who focused their main research interest on the issue of scaling the companies' yield of industrial goods, its planning and supervision of inventories, as well as type design practice and customization of the produced goods ${ }^{21}$. Giving respect to Western scholars' theoretical developments in the field of general

\footnotetext{
${ }^{14}$ Porter M. E. Competitive Strategy: Techniques for Analyzing Industries and Competitors. New York: The Free Press, 1980 .

${ }^{15}$ Ghoshal S., Bartlett C. A. The multinational corporation as an interorganizational network. Academy of management review. 1990. No. 15. P. 603-626. Bartlett C. A., Ghoshal S. Managing across borders: The transnational solution. Vol. 2. Harvard Business School Press, 1999.

${ }^{16}$ Rugman A. M., Verbeke A. Extending the theory of the multinational enterprise: internalization and strategic management perspective. Journal of International Business Studies. 2003. No. 34. P. 125-137. 2006.

${ }^{17}$ Buckley P. J. Multinational Enterprise and the Globalization of Knowledge. New-York: Palgrave Macmillan,

18 Rohach O. Teorii mizhnarodnoho biznesu. K.: VPTs «Kyivskyi universytet», 2018. S. 549-582. [In Ukraianian].

19 Taylor F. W. The Principles of Scientific Management. New York: Harper \& Brothers. 1911.

${ }^{20}$ Harris F. W. How Many Parts to Make at Once. Operations Research. 1990. Vol. 38. №6. P. 947-950. Shewhart W. A. Economic control of quality of manufactured product. New York: D. Van Nostrand Company, 1931

${ }^{21}$ Stapran D. A. K voprosu o teorii i praktike (aut)sorsinga. Rossiyskoe predprinimatelstvo. 2016. T. 17. No. 7. S. 847. [In Russian].
} 
management theory, we believe that the theoretical background of the international labour division formed the framework for the development of a number of modern management concepts that explain setting the stage for transfer abroad some of the companies' own production, financial and management facilities. In our opinion, the most deserving concepts are the concepts of Total Quality Management (TQM); Lean Production and Business Process Re-engineering $(B P R)$. From the point of view of offshore business segment, the mentioned management theories to the greatest extent reflect, in our opinion, its nature and economic essence as their methodological background is focused on explanation of key driving forces of boosting business efficiency, global business structures of companies, business process management systems and their redesign in order to transform the business processes to support strategic change and ensure long-term competitive advantages in the market.

Describing the tax paradigm of the theoretical discourse of offshore business processes, it should be noted that it develops in the general framework of conceptual understanding of means influenced on national tax systems on corporate investment decisions, currency and operational risk management, capital asset structure planning and internal corporate flow management. These conclusions follows from the direct influence of the above areas of multinational enterprises strategic management on the formation processes of revenues generated by them, their distribution between structural units of the companies and taxation. Among the general theories of taxes, which formed the "backbone" of the methodological understanding of the offshore business processes, in our opinion, tax theory of services, atomistic theory, classical tax theory, and theory of social needs are worth paying more attention. They are united by a single methodological platform, namely: a comprehensive explanation of the economic nature of taxes and fixing their role in the economic system of society.

In a comprehensive study of the tax paradigm of the theoretical discourse of the offshore business processes, we cannot neglect the Keynesian theory, which emerged as an expected response of macroeconomic policies of top global countries to large-scale structural changes in the global economic system of the first quarter of the 20th century. First, it is about its rapid monopolization and transnationalization, which have clearly confirmed the critical inability of the spontaneous market tools and intersectoral capital transfer, free competition and free pricing system to fix and automatically maintain macroeconomic balance. Thus, in his paper "General Theory of Employment, Interest and Money" J. Keynes emphasizes the need for the state to implement a dynamic fiscal policy in order to ensure full employment and strengthen macroeconomic growth. Its main tools are to supply and demand propelling through scaling up public procurement and reducing the 
tax burden on business in times of crisis and recession in national economic cycles.

The neoclassical direction of economic theory, which found its deepest development in the works of such scientists as F. Wieser, J. Clark, A. Laffer, A. Marshall, J. Mead, W. Pareto, A. Pigou, R. Solow, J. Tucker, M. Friedman, R. Harrod, etc. ${ }^{22}$ was crucial to the development of a regular theoretical discourse of the business taxation issues. The key idea of the neoclassical concept in the development of the tax paradigm of offshore business is a theoretical position on the need for the state to ensure its steady growth of quality living conditions by permanently raising the minimum salary and thus supporting financial conditions to meet their primary economic interests, needs and demands. Thus, one of the most meaningful modern-wise scientific ideas of $F$. Wieser is the statement that the state prevents the loss of income by citizens, able to ensure a sufficient level of their personal earning capacity ${ }^{23}$. In turn, within the structure of national expenditures A. Marshall fixes the expenditures on the appropriate living conditions for the working population, qualifying them as a priority costs. Being a supporter of the policy of accelerated growth of the minimum wage and maintaining it at the subsistence level, the scientist considers it as the key guarantee of improving the social welfare of the population.

Finally, the institutional paradigm of the theoretical discourse of offshore business processes in its methodological background is based on the key features of the company's market patterns in its interaction with various social institutions. The fundamental background of this paradigm was fixed in the papers of T. Veblen, W. Mitchell, J. R. Commons, J. K. Galbraith, J. Schumpeter, J. Tinbergen, and many other scientists who developed a logical theory of transaction costs. Thus, thanks to J.R. Commons the "transaction" notion gets its "scientific residence" in theoretical discourse. It fixes the essential background of the theory of transaction costs related to market transactions, exchanges and non-market interactions ${ }^{24}$.

Another founder of the institutional field of economics, T. Veblen, focused his research interest on a system of factors that directly influence the market behaviour of economic agents, while prioritizing their monetary incentives ${ }^{25}$. At the same time, W. Mitchell ${ }^{26}$ explained the existence of a close correlation

${ }^{22}$ Clark J., Cole S. Global Simulation Models: A Comparative Study. New York: John Wiley \& Sons, 1975. Friedman M. The Methodology of Positive Economics. In: M. Friedman. Essays in Positive Economics. Chicago, 1958. Marshall A. Principles of Economics (ukr. Printsipyi ekonomicheskoy nauki): V 3 t.: transl. from Eng. M.: Progress, 1993. Pigu A. Ekonomicheskaya teoriya blagosostoyaniya. T. 2. M., 1985. [In Russian].

${ }^{23}$ Istoriia ekonomichnykh uchen: Pidruchnyk / [V. D. Bazylevych, T. V. Haidai, N. I. Hrazhevska ta in.]; za red. V. D. Bazylevycha. K.: Znannia, 2004. S. 520. [In Ukrainian].

${ }^{24}$ Tymoshenkov I. V. Nashchekina O. M. Transaktsiini vytraty opodatkuvannia yak skladova mizhnarodnoi konkurentospromozhnosti krainy. Ekonomichna teoriia ta pravo. 2017. No. 4. S. 39. [In Ukrainian].

${ }^{25}$ Veblen T. The Theory of Business Enterprise, 1904.

${ }^{26}$ Mitchell U. Ekonomicheskie tsiklyi: Problema i ee postanovka. M. — L.: Gosizdat, 1930. [In Russian]. 
between internal and external factors of market behaviour of business entities, in terms of the degree of relationship between economic (profit, profitability, credit interest, market supply and demand, etc.) and ethical and behavioural reasons of their business transactions ${ }^{27}$. From the current standpoint of global offshore business processes, the institutional focus area of its theoretical discourse contains many meaningful and competent scientific ideas. It is, in particular, about the interpretation of the economic nature of institutions as a group action to supervise, ease up on restrictions and expand individual activity (D. Commons) ${ }^{28}$; as the background of public life, the system of formal and informal rules of economic behaviour, observation instruments and enforcement to follow them; and principles of interaction of individuals, corporations, trade unions, and nation-states (J. Campbell) ${ }^{29}$.

The development of institutional paradigm of the theoretical discourse of business offshoring processes through transaction costs is also associated with the names of K. Dalman, K. Arrow, R. Coase, S. Crawford, J. Marshak, D. North, E. Ostrom, J. Stigle, etc ${ }^{30}$. Thus, the scientific research of R. Coase in his landmark paper "The nature of the firm" has a detailed explanation of the economic nature and significance of transaction costs and property rights for the institutional structure of society and the functioning of its economic system. Considering markets and companies as alternative path of conducting business transactions ${ }^{31}$, R. Coase gives his own explanation of transaction costs as those that arise in economic entities due to the imperfection of economic systems in course of signing agreements, negotiating with counterparties, supporting cooperation with them and eliminating of existing differences in approaches. Thus, transaction costs are critical for the theory of the firm and are linked to the costs of using the market tool ${ }^{32}$ : on the one side, the "invisible hand" of market management of the resources' allocation, and on the other side, the "visible hand" of the manager who supervises the resources' allocation of the enterprise itself ${ }^{33}$.

With the above said, the offshore business being by theory determined by the classics of political economy two centuries before its actual appearance in the international economic practice, has gained the fullest conceptual reflection in the pattern of international business, management, tax and

${ }^{27}$ Hlobalnyi rynok intelektualnoi vlasnosti: monohrafiia / O. Yu. Bilenkyi, Ya. M. Stoliarchuk, O. M. Halenko, V. M. Stoliarchuk. Kyiv: Feniks, 2016. S. 47. [In Ukrainian].

${ }^{28}$ Commons R. J. Institutional Economics. American Economic Review. 1931. Vol. 21. P. 648-657.

${ }^{29}$ Campbell J. L. Institutional Change and Globalization. Princeton and Oxford: Princeton University Press, 2004

${ }^{30}$ Crawford S., Ostrom E. A Grammar of Institutions. American Political Science Review. 1995. Vol. 89. No. 3. September. Pryroda firmy: pokhodzhennia, evoliutsiia i rozvytok / za red. O. I. Viliamsona, S. Dzh. Vintera. Per. Z anhl. A. V. Kulykova. K.: A.S.K., 2002. [In Ukrainian].

${ }^{31}$ Coase R. Firma, ryinok i pravo. Per. s angl. M.: Novoe izdatelstvo, 2007. S. 7-35. [In Russian].

${ }^{32}$ Coase R. H. The nature of the firm. Economics. 1937. V. 4 (5).

${ }^{33}$ Izhevskyi P. H. Teoretychni zasady formuvannia biznes-merezh na bazi teorii transaktsiinykh vytrat. Hlobalni ta natsionalni problemy ekonomiky. 2016. Vypusk 12. S. 255. [In Ukrainian]. 
institutional business pattern. All of them, from the standpoint of their own scientific matter, consider business offshoring as a current concept for supporting effective and competitive organizations based on improving their business functions and processes. In course of constant development and enriching, these patterns reflect qualitatively new trends in the international practices of companies, while the constant support of new scientific schools and areas is accompanied by the dynamic inclusion of offshore business in the field of research of domestic and foreign scientists. This is the basis for fixing of conventional approach for the active use of its tools in the actual international business practice of economic entities of different levels and nationalities.

\section{Competitive advantages of offshore business for economic entities}

Offshore business, which originated in the second half of the 1950s, was an expected result of two groups of determining factors: on the one hand, the easing of military and political global tension, and on the other - a number of former British colonies got independence. Aiming the strategic goal of attracting foreign capital into their national economies and thus resolving the most acute social, economic, and political issues, at that time they became a kind of vectors of development of global networks of offshore jurisdictions. The former British colonial possessions were mainly aimed at servicing foreign companies registered in their territory by introducing preferential tax regulations ${ }^{34}$ for them on the basis of making appropriate regulatory changes in domestic laws.

On the other hand, many former British colonies, having obtained the status of offshore jurisdictions, began to be actively used by Britain as important institutions to support British influence on the entire system of international business relations. This became a reason that is even more important after the adoption of the Glass-Steagall Act in the United States in 1933, which introduced a mandatory functional principle of regulation of the American financial market with the separation of credit and deposit and investment operations of banking institutions and the introduction of strict interest rate limits for fixed-term and saving bank deposits. With this in mind, Eurocurrency transactions carried out by the US banks through the offshore centres of the former British colonies, gave them almost unlimited opportunities to evade the Glass-Steagall law in terms of piling-up the global deposit base and the implementation of euro credit transactions. In other words, from the second half of the 20th century, various offshore operations

\footnotetext{
${ }^{34}$ Puzakova E. P., Shepel T. S. Soderzhatelnaya struktura protsessa ofshorizatsii mirovoy ekonomiki s pozitsiy urovnevogo podhoda. Natsionalnyie interesyi: prioritetyi i bezopasnost. 2015. No. 10 (295). S. 58. [In Russian].
} 
supporting tools and practices show agile development within the British financial system.

It is worth noting that the direct developers and users of different offshore tools at all stages of its evolutionary development were presented by top countries interested in the functioning of networks of international financial centres and tax havens in order to use them to gain control over the companies and businesses of different global economy sectors. Thus, in recent decades the agile offshore operations in global business models has led to a general trend of reducing legal pressure on the global financial sector and the rapid development of financial capitalism, which involved more and more countries and regions.

The financial core of the current offshore business practice is large-scale cross-border operations with capital resources, including procedures for listing securities on international stock exchanges, protection of assets from unfriendly takeovers, simplification of procedures for their sale or change of ownership, use of capital protection guarantees for foreign investors, etc. Suffice it to say that currently, according to Tax Justice Network, the international research organization, the offshore jurisdictions have accumulated unregistered investment capital totalling from USD 21 to USD 32 trillion ${ }^{35}$,, which accounts for about a third of global gross domestic product. This amount does not include the registered real estate accounting for about USD 70 trillion US dollars, or 30-45 percent of the global GDP ${ }^{36}$. According to Ballpark Expert Agency, the annual losses of the US economy from the implementation of tax reduction patterns by US business entities amount to over USD 450 billion, while the Internal Revenue Service manages to return no more than a ninth of this amount (about USD 52 billion) ${ }^{37}$. In general, if multinational enterprises fully account their profits in the countries in which they operate, they would be obliged to pay an additional USD 500-650 billion income taxes. Of this amount, about USD 200 billion would go to developing countries ${ }^{38}$, and thus would significantly reduce their needs for external financing, primarily the official development assistance.

Competitive advantages of offshore business such as process optimization, grabbing of new market segments, bigger access to a highly skilled personnel, avoiding of institutional barriers to cross-border flow of goods, services and production factors, improving the customer service practices, as well as

35 The Price of Offshore Revisited. New Estimates for Missing Global Private. Wealth, Income, Inequality, and Lost Taxes. Tax Justice Network, July 2012. P. 5.

${ }^{36}$ Redziuk E. V. OfshorizatsIya svItovoyi ekonomiki: perspektivi dlya Ukrayini i svitu. Visnik Asotsiatsiyi doktoriv filosofiyi Ukrayini. 2015. No. 1. URL: http://aphd.ua/publication-34/ [In Ukrainian].

${ }^{37}$ Andielic J. Tax Evasion Statistics: Just How Damaging Is it to Not Pay Your Taxes? Fortunly, July 9, 2019. URL: https://fortunly.com/statistics/tax-evasion-statistics/\#gref

38 These five countries are conduits for the world's biggest tax havens. The Conversation, July 24, 2017. URL: https://theconversation.com/these-five-countries-are-conduits-for-the-worlds-biggest-tax-havens-79555 
streamlining the accounting system for financial and business transactions can also contribute to companies. It should be noted that in this way in recent decades the global economy supports the new-type multinational enterprises engaged in production for and servicing of third-party companies in the format of manufacturer-contractor and agile development in global frameworks of international networks of foreign branches. In this way, they gain unsurpassed competitive advantages in the global model of the international labour division, as evidenced, in particular, by their broad options to avoid paying taxes totalling about USD 90 billion annually. At the same time, according to Fortune 500 rating, 362 corporations have subsidiaries in international offshore tax havens such as Bermuda or the Cayman Islands. At the same time, all involved companies would be obliged to pay annually an extra USD 147.5 billion tax fees in case of full registration of profit gained in the US ${ }^{39}$.

\section{Financial and currency imperatives of offshore business}

Since the early 1980s, the entry of the global economy into the phase of its historical progress radically changes the development approach of offshore business processes both in terms of their driving forces and in terms of vector and implementation tools. This is affected by rapid increase in the use of offshore capital by business and enterprise entities, with transformation of offshore areas with different location into a global network of global financial centres integrated within the technological, instrumental and regulatory framework. The latter provide non-residents with a wide range of financial services in amounts significantly exceeding the capitalization of national financial markets of countries of their registration ${ }^{40}$, thus having a powerful a great influence on accelerating cross-border global financial flows, optimizing the international capital turnover and fixing the new cutting-edge qualitative and quantitative global business patterns.

It should be noted that back in the 1990s, over 50 percent of the global money passed through offshore jurisdictions, they managed about 20 percent of the total global wealth and accumulated over 22 percent of external banking assets ${ }^{41}$. Currently, according to unofficial data, there are about 3540 targeted global offshore jurisdictions engaged in servicing over 50 percent of all global financial transactions. This is without consideration their share

${ }^{39}$ Andielic J. Tax Evasion Statistics: Just How Damaging Is it to Not Pay Your Taxes? Fortunly, July 9, 2019. URL: https://fortunly.com/statistics/tax-evasion-statistics/\#gref

${ }^{40}$ Zorome A. Concept of offshore financial centers: In search of an operational definition. IMF Working Papers. WP/07/87. April 2007; Makarov V. V., Makarova Yu. S. Organizatsiya offshornogo predprinimatelstva v usloviyah globalizatsii ekonomiki. SPb., 2001. S. 23. [In Russian].

${ }^{41}$ Heyfets B. A. Ofshornyie finansovyie seti v mirovoy ekonomike / Geografiya mirovogo razvitiya. Vyipusk 2: Sbornik nauchnyih trudov / Pod red. L. M. Sintserova. M.: Tovarischestvo nauchnyih izdaniy KMK, 2010. S. 84. [In Russian]. 
in the global gross domestic product, which does not exceed 1.2 percent, if excluding industrial production and agriculture sectors -0.8 percent $^{42}$. Currently, the value of private capital accumulated in offshore jurisdictions is about USD 7 trillion (the lion's share of which was obtained from illegal operations), and USD 1 trillion is an increase in government revenue that can be obtained by reducing global corruption by a third ${ }^{43}$. As we can see, these figures reflect the "dark segments" of the global economic system and money circulation, as well as illegally obtained income from bribery and regulatory arbitrage not covered by tax, regulatory and law supervision. Together, they cause irreparable damage to public welfare and increase the disbalance of global economic development.

Currently, there are five groups of global drivers of offshore sector, each having its particular tools and influence instruments on its structural dynamics, the scale of accumulation and cross-border flows of capital assets, as well as competitive struggle of locally different businesses for tax administration benefits. At the same time, we should consider one more important thing: by using dialectical method of studying the economic processes and phenomena, we claim that with maintaining the conventional factors of business offshoring, these key factors fix breakthrough patterns and trends in accordance with the laws of global progress. On the other hand, the global vector of offshore business processes is currently influenced by both real-life economic laws and nonlinear and emergent factors of social progress, ensuring their breakthrough properties not typical to any of its components because of synergistic links between them. This fact causes a significant escalation of the contradictions of state and corporate economic interests, which requires the implementation of cutting-edge instruments for their mitigation, and if possible, smooth-up in full.

The first group of globalization imperatives of offshore business is represented by financial and monetary factors related to the regular influence of the financial globalization processes. Financial globalization is the key component of the regular processes of economic globalization, therefore it has a truly pioneering impact on all structural subsystems of the global business sector, with significant expansion of the cross-border flows of capital assets of economic entities and their ability to deeply "embed" in global sales, transport and logistics and scientific and technical networks. Within recent decades, against the background of a slowdown in global production of goods and services, there has been an agile increase in the value of global financial assets, which include joint capitalization of national stock markets, domestic and foreign debt of states and business sector, and bank deposits.

\footnotetext{
${ }^{42}$ Puzakova E. P., Shepel T. S. Soderzhatelnaya struktura protsessa ofshorizatsii mirovoy ekonomiki s pozitsiy urovnevogo podhoda. Natsionalnyie interesyi: prioritetyi i bezopasnost. 2015. No. 10 (295). S. 59. [In Russian].

${ }^{43}$ Lipton D. Shining a Light. Bringing money out of the shadows means improving governance. Finance \& Development, September 2019. P. 4.
} 
In particular, in 2010 they amounted to about USD 600 trillion, and currently - USD 900 trillion (Fig. 1), at least ten times higher than global $\mathrm{GDP}^{44}$.

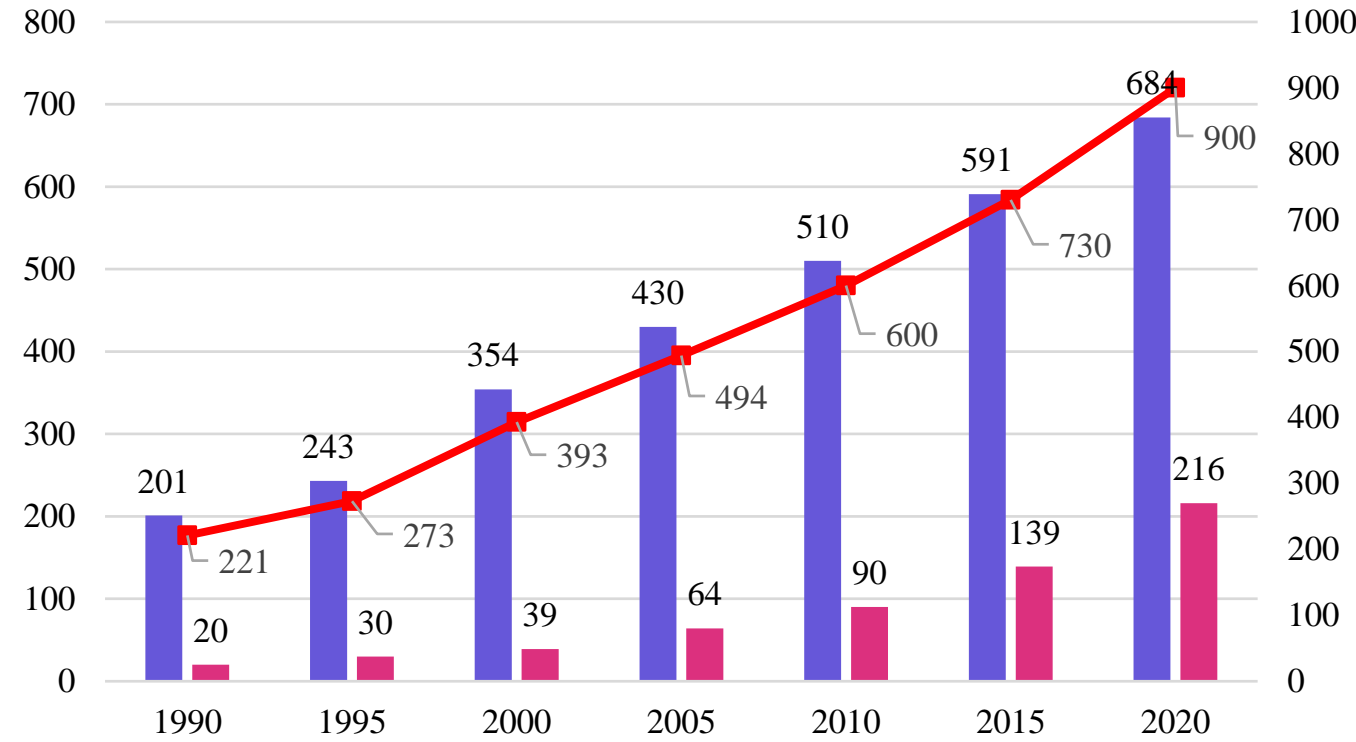

Financial assets of developed countries, trillion USD, left chart

Financial assets of developing countries, trillion USD, left chart

-Global financial assets, trillion USD, right chart

Fig. 1. Value of financial assets by different groups of countries in 1995-2020, trillion USD

Source: calculated and built according to: A World Awash in Money. Capital trends through 2020. Bain \& Company, 2012. P. 10.

Let's turn to the figures: as of late 2019, the average daily value of trades in bonds of the State Treasury of the United States of America reached almost USD 150 billion; shares of the most capitalized companies on S\&P 500 list - USD 149.2 billion; gold - USD 145.5 billion; bonds issued by the British government - USD 44 billion; US corporate bonds - USD 33.9 billion ${ }^{45}$. In the United States, capital markets currently provide 72 percent of total

\footnotetext{
${ }^{44}$ A World Awash in Money. Capital trends through 2020. Bain \& Company, 2012. P. 3.

${ }^{45}$ Leading major financial assets worldwide as of December 2019, by average daily trading volume (in billion U.S. dollars). Statista. The Statistic Portal. URL: https://www.statista.com/statistics/625422/daily-trading-volumesof-major-financial-assets-worldwide/
} 
economic financing, supporting the necessary conditions for large-scale borrowing by the public and private sectors ${ }^{46}$.

International experts say that due to its enormous value volumes global financial capital forms self-generating and self-sustaining impulses to increase the capitalization of the global financial market. They are a crucial factor in the "deformation" of international investment decisions of economic entities, setting dangerous to global economic strength local points of capital accumulation, while blocking access to it by those entities operating in areas with high business risks ${ }^{47}$. Note also the rapid increase in the capitalization of financial markets in developing countries: if in 1990 their share in the value of global financial assets did not exceed 9 percent, in $2020-24$ percent ${ }^{48}$

We believe that the multi-channel impact of financial globalism on the transformation of offshore business is primarily related to the regular relaxation of national financial markets and deregulation of international banking transactions, internationalization of accumulation processes, capital use and appropriation, wide admission of non-residents to stock market operations. In particular, in recent decades one of the most powerful drivers of offshore business development was the development in the first half of the 1980s in the United States of a network of international banking areas with preferential tax regimes. They were used by all foreign banking institutions operating in the United States at the time to be exempted from reserve requirements. We must also mention the entry into force in 1978 of the US Law on International Banking, which gave foreign banks the right to establish so-called Edge corporations. They tend to carry out targeted financing and international banking operations, equity investments in stock instruments of foreign banks and financial companies, servicing foreign borrowers in the purchase of long-term bills and bonds, etc. ${ }^{49}$.

The introduction of new rules on opening the foreign branches of American banks and their foreign investment made by the US Federal Reserve in 1979 also deserves particular attention; adoption of the Rigl-Nile Law in 1994; abolition of the Glass-Steagall Act in 1999 (which was replaced by the Gramm-Leach-Bliley Financial Services Modernization Act ${ }^{50}$ ), etc. Together, they removed a number of existing restrictions on cross-border banking operations $^{51}$, mandatory separation of deposit and investment operations of

462020 Capital Markets Fact Book. SIFMA, September 2020. P. 6.

47 A World Awash in Money. Capital trends through 2020. Bain \& Company, 2012. P. 3.

${ }^{48}$ A World Awash in Money. Capital trends through 2020. Bain \& Company, 2012. P. 10.

49 Bankovskoe delo: zarubezhnyiy opyit i kazahstanskaya praktika: uchebnoe posobie / U.Aytbaeva, K.Ahmetova, II.Kolebaeva i dr. Almatyi, 2004. URL: https://economics.studio/bank-delo/925-offshorno-onshornyiebankovskie-23495.html [In Russian].

50 Finansovi rynky Pivdenno-Skhidnoi Azii: dyversyfikatsiina panorama: monohrafiia / O. M. Halenko, Ya. M. Stoliarchuk, A. V. Shlapak. — K.: Feniks, 2016. S. 142. [In Ukrainian].

${ }_{51}$ Heyfets B. A. Ofshornyie yurisdiktsii v globalnoy i natsionalnoy ekonomike: monografiya. M: ZAO «Izdatelstvo «Ekonomika», 2008. S. 40. [In Russian]. 
banking institutions, regulation of interest rates on time and savings deposits, mergers and acquisitions of holding banks with investment banks, companies with asset management, insurance companies and non-bank financial intermediaries ${ }^{52}$.

The currency liberalization tools also have a strong influence on current offshore business transformations, namely: removing of currency restrictions and introduction of the policy of mutual convertibility of key reserve currencies, weakening of interstate supervision over currency exchange, internationalization of a number of national currencies of former outsiders of global economic processes, etc. An example is China, which, in the last decade, has implemented a rather aggressive policy of the yuan internationalizing to set up a global network of its currency, to become an important payment means in trade, bank lending and electronic transfers, and to expand the country's influence on regional financial pattern. This global project was launched back in 2008, when it was announced the yuan use in international trade settlements between companies in some provinces of South China with their counterparts from neighbouring Hong Kong, Macao and ASEAN. Although China still has rather strict regulatory restrictions on the implementation and conduct of forex trading, however this area is already being strongly liberalized. First of all, it is a question of restrictions' removal on interbank trading operations with auction and commodity derivatives, granting to a number of Chinese non-financial and non-banking institutions an access to swap operations of foreign exchange markets, etc ${ }^{53}$. As a result, we faced a dynamic increase in the value of the yuan's foreign exchange turnover in key segments of the global offshore market, as well as the formation in Hong Kong of offshore trading centres for the international yuan, the renminbi. Within 2004-2020 the value of yuan-denominated renminbi deposits increased from 12.1 to 694.9 billion $^{54}$. We can also see that the current offshore yuan deposits are no longer limited to Hong Kong, while the agile growth of yuan global use has ensured its deep penetration into the transaction of various offshore clearing centres, as well as the introduction of a market segment for Chinese companies to place their external debt in yuan.

\section{The nature of impact of transnationalization imperatives on the diversification of offshore business operations}

Transnationalization imperatives as the second group of globalization factors are also a powerful trigger for scaling up and diversifying the

\footnotetext{
52 Finansovi rynky Pivdenno-Skhidnoi Azii: dyversyfikatsiina panorama: monohrafiia / O. M. Halenko, Ya. M. Stoliarchuk, A. V. Shlapak. — K.: Feniks, 2016. S. 142. [In Ukrainian].

53 Ibid, p. 219

${ }^{54}$ Renminbi deposits. Hong Kong Financial Authority. URL: https://www.hkma.gov.hk/eng/data-publicationsand-research/data-and-statistics/monthly-statistical-bulletin/table/
} 
structure of offshore business processes. They are linked to the full involvement of national economies in the manufacturing networks and fragmented production of multinational enterprises, regular strong flows of their foreign direct and portfolio investment, diversification of organizational patterns of the multinational enterprises. The need for us to single out transnationalization imperatives for offshore business segment is caused by the reasons of financial and economic practices of multinational enterprises, which are known to be the largest owners and, therefore, suppliers (direct or indirect) of global offshore capital. This became possible due to the introduction of a huge number of legally independent or included in the transnational reproduction cycle and comprehensively dependent companies in the organizational framework of the multinational enterprises.

Due to the rapid increase in the scale of its foreign investment, within recent decades the multinational enterprises have introduced global networks of production segment, distribution of trade flows and financing of business operations. They meet the needs of global consumers not only in goods and services, but also in the settlement service of their supplies, different types of credit capital, currency exchange and securities trading, diversification of insurance risks and financial services of cross-border capital flows, etc. Largescale financial and business operations of multinational enterprises increased the global demand for sources of international credit capital, not related to the current national restrictions on its cross-border flows ${ }^{55}$.

At the same time, the use of offshore companies supports effective structuring of multinational enterprises business practice by reducing the transaction costs of key divisions. This is possible by sufficient excess of the amount of tax savings received by companies from the use of offshore patterns over their total costs of maintaining the functioning of offshore segment. Currently, according to the OECD, over a third of global bank deposits (about USD 11.5 trillion) are concentrated in the largest offshore business centres $^{56}$; and over 80 of the top-100 corporations have foreign affiliates, about 60 of them - in offshore jurisdictions.

In particular, in the UK, only 2 of top-100 capitalized companies listed on the London Stock Exchange do not use the services of offshore jurisdictions, while others have over 8 thousand registered offshore subsidiaries due to which the British annual tax losses are estimated at GBR 18.5 million $^{57}$. In the United States, 83 of 100 corporations whose shares are traded on stock exchanges have offshore subsidiaries. Moreover, we'd like to note that the average level of the effective rate of their income tax does not

\footnotetext{
${ }^{55}$ Redzyuk E. V. Ofshorizatsiya svitovoyi ekonomiki: perspektivi dlya Ukrayini i svitu. Visnik Asotsiatsiyi doktoriv filosofiyi Ukrayini. 2015. No. 1. URL: http://aphd.ua/publication-34/ [In Ukrainian].

${ }^{56}$ Ibid.

${ }^{57}$ Puzakova E. P., Shepel T. S. Soderzhatelnaya struktura protsessa ofshorizatsii mirovoy ekonomiki s pozitsiy urovnevogo podhoda. Natsionalnyie interesyi: prioritetyi i bezopasnost. 2015. No. 10 (295). S. 60. [In Russian].
} 
exceed 2.3 percent at the nominal rate of federal corporate income tax at 35 percent $^{58}$. In general, the global ratio between the number of multinational enterprises and the number of their branches is now 1: 9.9; for developed countries - 1: 4.5; and for developing countries $-1: 22^{59}$.

All these processes in recent decades resulted in a specific phenomenon, which has been very accurately described as "offshore pollution" or "offshore saturation"60 (depending on the attitude to offshore institutions by national governments and institutions of global economic management). At the same time, offshore jurisdictions themselves pose serious challenges to the closed nature of national financial systems, introducing all the necessary institutional preconditions for accelerating their liberalization, scaling up cross-border financial transactions and speculative transactions of economic entities, and increasing the transfer of surplus financial assets on futures platforms of global commodity markets.

\section{Institutional and regulatory imperatives of global offshore business}

The third group of globalization imperatives of offshore business is institutional and regulatory determinant factors. They are related to the removal of traditional barriers to the cross-border flows of goods and services within the World Trade Organization, liberalization of national commodity markets and tax systems, global expansion of the market economy, escalation of international tax competition, etc. According to global experience, the current offshore sector introduces a significant share of global trade in goods and services ${ }^{61}$, which is a natural result of both the triggering of transnational practice and the rapid growth of international trade. Together, they reasonably demand an increasing expansion of economic agents' access to credit capital at any local point of the international economic system. As a result, dynamic introduction and development of non-national capital asset markets on the basis of offshore transactions denominated in eurocurrencies. Their capitalization increased from USD 20 billion in 1964 to USD 6 trillion in the early $1990 \mathrm{~s}^{62}$, which is evidence of the dynamic growth of global demand from economic entities for deposit and credit operations in currencies that are out of control of

\footnotetext{
${ }^{58}$ Mudrak N. O. Natsionalni mehanizmi borotbi z uhilennyam vid opodatkuvannya cherez ofshorni yurisdiktsiyi v krayinah OESR. Naukoviy visnik Uzhgorodskogo natsionalnogo universitetu. Seriya Mizhnarodni ekonomichni vidnosini ta svitove gospodarstvo. 2019. Vipusk 25, chastina 2. C. 6. [In Ukrainian].

59 Heyfets B. A. Ofshornyie yurisdiktsii v globalnoy i natsionalnoy ekonomike: monografiya. M: ZAO «Izdatelstvo «Ekonomika», 2008. S. 50._[n Russian].

${ }^{60}$ Ibid, p. 38.

${ }^{61}$ Baula O., Sachuk A. Osoblyvosti evoliutsii ofshornykh zon v umovakh hlobalizatsii ekonomiky. Ekonomist. 2012. No. 1. S. 16._[In Ukrainian].

${ }_{62}$ Mirovaya ekonomika: globalnyie tendentsii za 100 let / Pod red. chlena-korrespondenta RAN I. S. Koroleva. M.: Yurist', 2003. S. 41. [In Russian].
} 
government currency regulators of issuing countries. Currently, according to the US Federal Reserve Bank, the average daily turnover of the Eurodollar market is about USD 140 billion, and the cost of one deposit transaction - from USD 25 million to USD 1 billion ${ }^{63}$.

This trend has not disappeared but also is recorded to scale up, gain diversified forms and levels of implementation within the years. Thus, today the daily volume of global foreign exchange transactions consistently exceeds USD 5 trillion $^{64}$, equalling to the half of the global foreign exchange reserves (USD 11.8 trillion in late 201965) and much exceeds the value of foreign exchange resources needed to service the global trading operations. We'd like to note that such dynamics of cross-border financial flows has led to a significant increase in convergence and interdependence of national loan capital markets around the world: if as of 1971 the total value of foreign assets of the banking system on deposits amounted to USD 208 billion, in 1980 - USD 1.8 trillion, in 1990 - USD 6.8 trillion, in 1995 - over 8 trillion $^{66}$, and currently - almost USD 30 trillion $^{67}$.

Describing the institutional and regulatory requirements of offshore business, we'd like to emphasize the critical influence of the networking processes of the global offshore system, which caused its dynamic spatial and territorial "growth". This is a kind of benchmark effect of offshore business services, when under the development by an offshore jurisdiction of any innovative tax loophole to attract and accumulate highly flexible financial capital, other jurisdictions are also beginning to follow it, offering innovative offshore products in the implementation of the socalled concession race model. As a result, in almost all global countries there is a steady decline of the average corporate income tax rates from 49 percent in 1985 to 24 percent as of today ${ }^{68}$. When weighing GDP, the average level of corporate income tax is 23.3 percent (Fig. 2) with the lowest average standard in Europe (20.3 percent and 25.1 percent when weighing GDP), and the highest - in the African region (28.5 percent and 28.2 percent respectively).

\footnotetext{
63 Chen J. Eurocurrency Market, March 13, 2020. URL: https://www.investopedia.com/terms/e/ eurocurrencymarket.asp

${ }^{64}$ Mizhnarodnyi dosvid rehuliuvannia rynku Foreks. Financial and Economic Analysis Office in the VRU. Kyiv, 2017. S. 4._[In Ukrainian].

65 Currency Composition of Official Foreign Exchange Reserves (COFER). IMF, 03.31.2020. URL: https://data.imf.org/?sk=E6A5F467-C14B-4AA8-9F6D-5A09EC4E62A4

${ }^{66}$ Mirovaya ekonomika: globalnyie tendentsii za 100 let / Pod red. chlena-korrespondenta RAN I. S. Koroleva. M.: Yurist', 2003. S. 41. [In Russian].

${ }^{67}$ Summary of foreign claims (immediate counterparty basis), by nationality of reporting bank. Amounts outstanding / Stocks at end December 2019, in billions of US dollars. Bank for International Settlements. URL: https://stats.bis.org/statx/srs/table/b2?m=S\&f=pdf

${ }^{68}$ Cobham A., Janský P. Measuring Misalignment: The Location of US Multinationals' Economic Activity versus the Location of their Profits. Development Policy Review. 2017. No. 37 (1). P. 98
} 
60

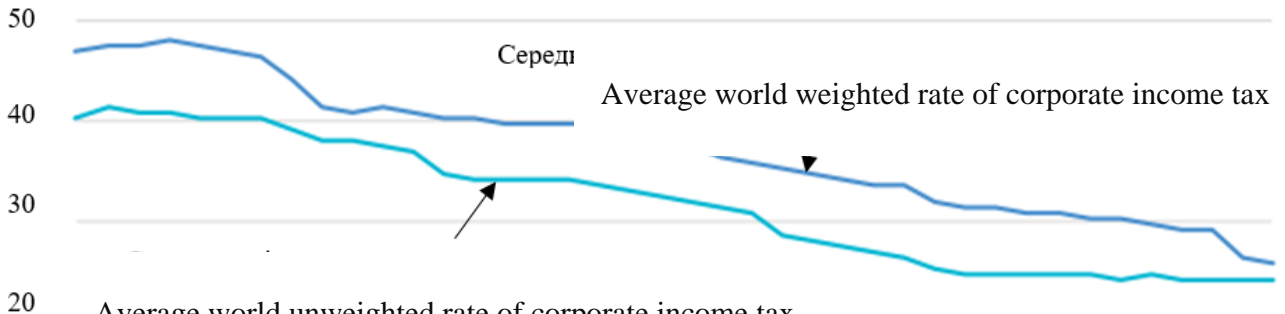

20

Average world unweighted rate of corporate income tax

10

0

$\begin{array}{lllllllllll}1980 & 1984 & 1988 & 1992 & 1996 & 2000 & 2004 & 2008 & 2012 & 2016 & 2019\end{array}$

Fig. 2. The global average weighted and unweighted corporate income tax rate in 1980-2019, percentage

Source: Asen E. Corporate Tax Rates around the World, 2019. Fiscal Fact. No. 679. Tax Foundation, December 10, 2019. R. 8. URL: https://files.taxfoundation.org/20191209111406/ Corporate-Tax-Rates-around-the-World-2019.pdf

In general, the average corporate income tax rate is 21.8 percent in the European Union, 23.6 percent in the OECD and 27.7 percent $^{69}$ in the G7, which confirms a rather wide range of variation, even among the top countries. In addition, we all saw a rapid increase in the share of profits of multinational US enterprises redistributed through offshore tax havens, from an estimated 5-10 percent of gross profit in the 1990s to 15-25 percent in the pre-crisis period of the 2000s and 25-30 percent as of today ${ }^{70}$.

As shown in table 1 , the current list of countries with the highest value of profits transferred by multinational enterprises to offshore jurisdictions includes such top-10 countries as the United States, Germany, Canada, China, Brazil, France, Mexico, In2dia, Great Britain, Italy and Spain. In total, they account for USD 606.6 brought by the multinational enterprise to offshore zones of gross income and failed to pay USD 122.1 billion tax fees.

${ }^{69}$ Asen E. Corporate Tax Rates around the World, 2019. Fiscal Fact. No. 679. Tax Foundation, December 10 2019. P. 1. URL: https://files.taxfoundation.org/20191209111406/Corporate-Tax-Rates-around-the-World-2019.pdf

${ }^{70}$ Cobham A., Janský P. Measuring Misalignment: The Location of US Multinationals' Economic Activity versus the Location of their Profits. Development Policy Review. 2017. No. 37 (1). P. 98. 
Table 1

TOP 10 COUNTRIES ACCORDING TO PROFITS PARKED BY MULTINATIONAL ENTERPRISES IN OFFSHORE JURISDICTIONS IN 2017

\begin{tabular}{|l|c|c|c|c|c|}
\hline \multirow{2}{*}{ Country } & \multicolumn{2}{|c|}{ Gross profit shifting } & \multirow{2}{*}{$\begin{array}{c}\text { The amount of } \\
\text { unpaid taxes, } \\
\text { billion US } \\
\text { dollars }\end{array}$} & $\begin{array}{c}\text { The average } \\
\text { level of the } \\
\text { effective tax } \\
\text { rate }\end{array}$ & $\begin{array}{c}\text { Share of } \\
\text { global shifted } \\
\text { profits, } \\
\text { percent }\end{array}$ \\
\hline USA & 463.0 & 38 & 84.8 & 18 & 71 \\
\hline Germany & 25.8 & 154 & 7.1 & 28 & 4 \\
\hline Canada & 23.5 & 33 & 3.0 & 13 & 4 \\
\hline China & 15.0 & 65 & 2.6 & 17 & 2 \\
\hline Brazil & 14.3 & 98 & 3.7 & 26 & 2 \\
\hline Francent gross & 13.9 & 110 & 3.7 & 27 & 2 \\
\hline Mexico & 13.7 & 64 & 3.3 & 24 & 2 \\
\hline India & 11.4 & 184 & 3.6 & 32 & 2 \\
\hline Great Britain & 9.2 & 12 & 1.2 & 13 & 1 \\
\hline Italy & 8.6 & 187 & 4.2 & 49 & 1 \\
\hline Spain & 8.2 & 496 & 4.9 & 59 & 1 \\
\hline & & & & & 24 \\
\hline Other countries & 41.5 & 103 & 10.4 & & 6 \\
\hline
\end{tabular}

Source: Cobham A., Janskэ P. Measuring misalignment: The location of US multinationals' economic activity versus the location of their profits. ICTD Working Paper 42. November 2015. P. 22

\section{Influence means of social and financial key factors on global offshore business}

The fourth group of globalization imperatives of offshore business sector includes social and financial key factors linked to the rapid growth of world incomes, spiralling social disbalance at the domestic and interstate levels, growing accumulation of global wealth in the pockets of small number of global business barons and richest men. Thus, the last two decades have been marked by a rapid increase in the number of global wealthy citizens - people who own liquid financial assets with a total value of at least USD 1 million (high net worth individuals). Suffice it to say that from 2010 to 2018, their number increased as follows: in North America from 3.3 to 5.6 million people; APAC region - from 3.3 to 6.1 million; Europe - from 3.1 to 4.8 million; the Middle East - from 0.4 to 0.7 million; Latin America - from 0.5 to 0.6 million; Africa - from 0.1 to 0.2 million, respectively (Fig. 3). In general, the global indicator of personal financial well-being within 19992019 almost tripled - from USD 80.5 to USD 226.4 trillion, including North America - from USD 36.7 to USD 100 trillion, Western Europe from USD 22.3 to USD 46.8 trillion, Eastern Europe and Central Asia from USD 0.5 to USD 3.7 trillion, the Asian megaregion - from USD 5.1 
to USD 42.1 trillion, Japan - from USD 13 to USD 17.6 trillion, Latin America - from USD 0.6 to USD 5.6 trillion, the Middle East - from USD 1 to USD 4.2 trillion, Africa - from USD 0.3 to USD 1.6 trillion, Oceania - from USD 1 to USD 4.7 trillion, respectively ${ }^{71}$.

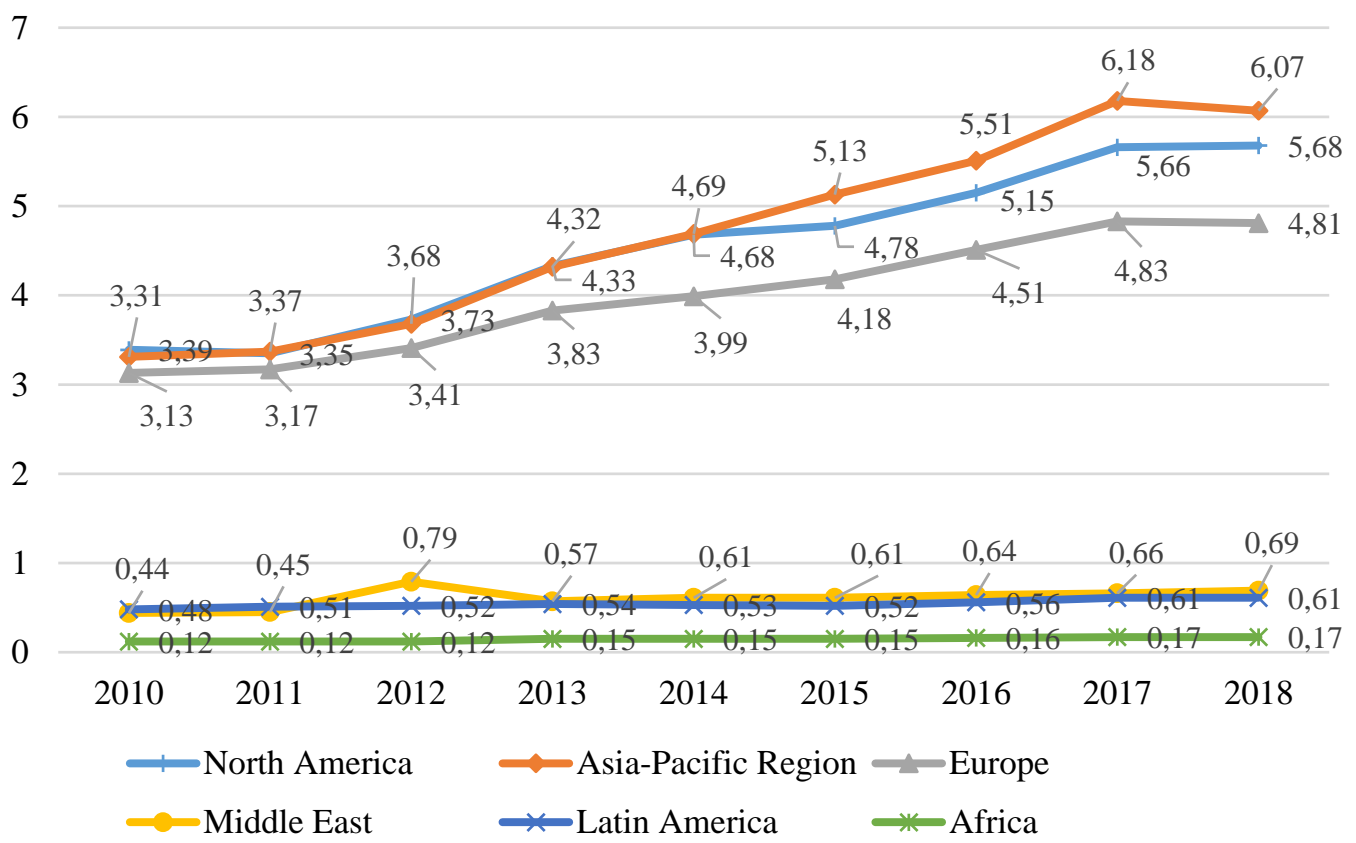

Fig. 3. The number of rich within the global populationin 2010-2018, million people ${ }^{72}$

It is worth noting that the richest men of the world can differ, because according to the in terms of quantity there are ultra-rich individuals among them (ultra high net worth individuals). The value of their net capital in eligible assets (i.e. excluding existing financial liabilities and investment in housing, works of art and leisure) is over USD 30 million. It should be noted that 13 percent of global wealth is now accumulated in the pockets of the super-rich people, although their number does not exceed 0.003 percent of

\footnotetext{
${ }^{71}$ Global Wealth 2020: The Future of Wealth Management. 20th Edition. A CEO Agenda. Boston Consulting Group, June 2020. P. 5

2 Number of high net worth individuals worldwide from 2010 to 2018 , by region (in millions). Statista. The Statistics Portal. URL: https://www.statista.com/statistics/263488/millionaires-worldwide-by-region/
} 
the world's population ${ }^{73}$; and each of about 1.4 thousand billionaires has a total wealth of over USD 1-2 billion ${ }^{74}$.

There is no doubt that so big assets by value and profile encourages its owners (especially from countries with unstable economies and political regimes) to widely use the offshore jurisdictions. The latter are used, in particular, to maintain control over capital assets and store their money in reliable foreign banks, the accumulation of tax-free revenues outside the fiscal jurisdictions of tax residence countries, structuring and strategic asset allocation, effective investment portfolio management, joint investment of private capital and real estate planning, etc. Let's consider the figures: currently, according to top international experts, individuals have "hidden" in tax "shelters" from USD $8.7^{75}$ to USD 36 trillion, which equals to about USD 200 billion personal income taxes underpaid to state budgets ${ }^{76}$.

Although these estimates significantly differ due to the high secrecy of financial transactions carried out through offshore jurisdictions, it is undeniable that they are widely used by the richest men of the world to circumvent financial regulations and taxation of their assets. This is confirmed by the changes of the global value of Assets under Management $(A u M)$, which within 2002-2017 increased from USD 27.3 to USD 79.2 trillion (in 2007 - USD 48.2 trillion, in 2008 - USD 39.3 trillion, in 2016 - USD 71 trillion $)^{77}$. As you can see, this figure is somewhat associated with the valuation of global financial assets of McKinsey and Boston Consulting Group, but due to the different profile of these assets is not equal to them, while its annual growth rate exceeds the average annual growth rate of gross domestic product. It's hard to imagine that BlackRock alone manages over USD 6.5 trillion assets, and the top three largest companies account for about 15.4 trillion managed assets (including Vanguard - 5.6 trillion, UBS -3.3 trillion) ${ }^{78}$.

We should not neglect the fact that the excessive global money concentration in the pockets of the super-rich men and the dominance of flexible financial assets in its profile, on the one hand, and public policy to mitigate deep social differences by combating illicit income, further capitalize the global demand for offshore jurisdiction services as reliable havens and accumulators of corporate and private capital. Global needs for such services are increase in response to a significant reduction of available foreign

\footnotetext{
${ }^{73}$ Ultra high-net-worth individual. URL: https://en.wikipedia.org/wiki/Ultra_high-net-worth_individual

74 Worldwide wealth distribution by net worth of individuals 2018. Statista. The Statistics Portal. URL: https://www.statista.com/statistics/203930/global-wealth-distribution-by-net-worth/

${ }^{75}$ Zucman G. How Corporations and the Wealthy Evade Taxes. New York Times, November 102017.

${ }^{76}$ Henry J. S. Taxing Tax Havens. Foreign Affairs, April 122016.

77 Value of assets under management worldwide in selected years from 2002 to 2017 (in trillion U.S. dollars) Statista. The Statistics Portal. URL: https://www.statista.com/statistics/323928/global-assets-under-management/

${ }^{78}$ Largest asset management companies worldwide as of March 2019, by managed assets (in trillion U.S. dollars). Statista. The Statistics Portal. URL: https://www.statista.com/statistics/431790/leading-asset-managementcompanies-worldwide-by-assets/
} 
investment in market segments due to the spread of acute crises in the global economy, caused by COVID-19 as well. With the above said, the offshore jurisdictions are considered as global institutions of comprehensive and challenging world wealth management processes in terms of models and implementation solutions.

\section{Information and communication imperatives of diversification of offshore business operations in a global environment}

Another group of globalization imperatives of offshore business sector is introduced by the system of information and communication factors. They are implemented in vast spread of innovative ICT in global finance segment, regular digitalization of cross-border financial flows, support and fast-paced development of business Internet platforms, widespread implementation in business practice of digital solutions and e-commerce instruments, etc. It should be noted that the development of new and advanced communication systems (Internet, banking networks, SWIFT-systems, mobile and satellite communications, etc.) related to globalization processes and cutting-edge software open up the companies a potential for prompt implementation of financial transactions for huge amounts over long distances globally.

The keen attention is given to global flows of digital information, which are shared via Internet channels and involve both Internet traffic and its cross-border segment. According to benchmarking Cisco's estimates, within 2018-2023 the average global broadband Internet traffic speed will increase from 45.9 to $110.4 \mathrm{Mbps}^{79}$, while in 2002 it did not exceed 100, and in 2016 $-26.6 \mathrm{Mbps}^{80}$. At the same time, cross-border information flows currently introduce about 3.5 gross domestic product and, according to respected international experts, will only grow in the short term, having the same impact on the global economy as international trade ${ }^{81}$. The degree of such influence is driven by the powerful and breakthrough effect of digitalization on global value chains introduced within multinational enterprises, which is an expected result of the sharpening of competition between conventional and new dynamic global market players who earlier missed any opportunities to participate in global economic relations and connections as their direct actors.

With this in mind, we believe that information and communication imperatives introduce a common institutional patterns of global offshore business practice based on the supporting and maintenance of real-time $24 / 7$

\footnotetext{
${ }^{79}$ Cisco Annual Internet Report (2018-2023) White Paper. Executive summary. March 9, 2020. URL: https://www.cisco.com/c/en/us/solutions/collateral/executive-perspectives/annual-internet-report/white-paper-c11741490.html

${ }^{80}$ Bereznoy A. Transnatsionalnyiy biznes v epohu globalnoy tsifrovoy revolyutsii. Mirovaya ekonomika $i$

mezhdunarodnyie otnosheniya. 2018. Tom 62. No.9. S. 6. [In Russian].
${ }^{81}$ Ibid.
} 
communication between the global major financial centres. Due to this connection, all entities of offshore operations (multinational enterprises and transnational banks, financial and investment funds, insurance and law firms, consulting and auditing firms, etc.) are united by the institutional platform of global offshore networks, the laws of which ensure their smooth operation under the preferential tax conditions, improving of corporate tax planning, as well as greater access to international stock and currency markets.

On the other hand, in the last decade, the Internet itself has not only become a robust information platform for the implementation of intercompany commercial transactions (within B2B and B2C trade practices), but also has become a benchmark influencing the processes of managing corporate income taxation. First, it is a question of sufficient simplification due to web-based operating procedures of registration of offshore companies and management patterns of so-called "mailboxes" companies, as well as essential reduction of the transport and logistics expenses at placement of corporate production centres by companies and business units. This is without consideration of fully "virtual companies", whose employees are working in different locations and communicate only through the Internet. This ensures the resolution of the key issue - avoiding the conflict of economic interests in terms of tax burden minimization and reducing business production and transaction $\operatorname{costs}^{82}$.

It is difficult to overestimate for the development of offshore operations the role of new IT solutions in the field of international payment systems. As an example, we can use the Cirrus debit card, which is widely used in the practice of offshore banking jurisdictions ${ }^{83}$. Compared to similar cards, its key competitive advantages for customers are, first, in the lack of requirements for declaring card funds when crossing the border; secondly, from a higher level of transactions' anonymity, when the bank only identifies the customer when issuing the card without indicating his name on the card and without notifying the name to third parties.

\section{Conclusions}

With the above said, we can note the following: the current stage of development of offshore business is marked by multi-channel impact of globalization imperatives, which is manifested at the level of financial and monetary, transnationalization, institutional and regulatory, social and property, information and communication factors. Their synergy has led to a kind of "autonomation" of offshore financial centres, their integration into a single global network and the gradual transformation of the latter into an

${ }^{82}$ Libman A. International Experience of Tax Optimization - The Role of Tax Competition and Offshores in Global Economy. Munich Personal RePEc Archive. MPRA Paper No. 17042, 2004. P. 55.

${ }_{83}$ Ibid, p. 56. 
independent and integral subsystem of the global financial market. At the same time, the fundamental reasons for the "blurring" of the tax base by corporate companies, its legal transfer of income or property assets to offshore jurisdictions cause a significant escalation of conflicts between state and corporate interests. This reasonably requires the global community to team up to counter the negative effects of multinational tax planning and the growth-based importance of offshore centres in the global financial practice. In this way, national economies will be able to effectively adjust to the challenges and threats of the global financial environment, as well as ensure efficient performance of international economic operations of their counterparties in order to introduce a favourable business environment for them and prevent non-transparent cross-border transfer of their capital resources.

\section{References}

1. 2020 Capital Markets Fact Book. SIFMA, September 2020. 2012 .

2. A World Awash in Money. Capital trends through 2020. Bain \& Company,

3. Aliber R. Z. A Theory of Direct Foreign Investment. The International Corporation, Ed. by Ch. Kindlberger, Cam., Mass., MIT Press, 1970.

4. Andielic J. Tax Evasion Statistics: Just How Damaging Is it to Not Pay Your Taxes? Fortunly, July 9, 2019. URL: https://fortunly.com/statistics/taxevasion-statistics / \#gref

5. Asen E. Corporate Tax Rates around the World, 2019. Fiscal Fact. No. 679. Tax Foundation, December 10, 2019. URL: https://files.taxfoundation.org/ 20191209111406/Corporate-Tax-Rates-around-the-World-2019.pdf

6. Bankovskoe delo: zarubezhnyiy opyit i kazahstanskaya praktika: uchebnoe posobie / U.Aytbaeva, K.Ahmetova, II.Kolebaeva i dr. Almatyi, 2004. URL: https: / / economics.studio/bank-delo/925-offshorno-onshornyie-bankovskie23495.html [In Russian]

7. Bartlett C. A., Ghoshal S. Managing across borders: The transnational solution. Vol. 2. Harvard Business School Press, 1999.

8. Baula O., Sachuk A. Osoblyvosti evoliutsii ofshornykh zon $\mathrm{v}$ umovakh hlobalizatsii ekonomiky. Ekonomist. 2012. №1. S. 16-18. [In Ukrainian].

9. Bereznoy A. Transnatsionalnyiy biznes $\mathrm{v}$ epohu globalnoy tsifrovoy revolyutsii. Mirovaya ekonomika i mezhdunarodnyie otnosheniya. 2018. Tom 62. No.9. S. 5-17. [In Russian].

10. Buckley P. J. Multinational Enterprise and the Globalization of Knowledge. New-York: Palgrave Macmillan, 2006.

11. Campbell J. L. Institutional Change and Globalization. Princeton and Oxford: Princeton University Press, 2004.

12. Casson M. C., Buckley P. J. The Theory of Internationalization. Recent Research on the Multinational Enterprise. London, 1991.

13. Chen J. Eurocurrency Market, March 13, 2020. URL: https://www.investopedia.com/terms /e/eurocurrencymarket.asp 
14. Cisco Annual Internet Report (2018-2023) White Paper. Executive summary. March 9, 2020. URL: https:/ /www.cisco.com/c/en/us / solutions / collateral / executive-perspectives / annual-internet-report/white-paperc11-741490.html

15. Clark J., Cole S. Global Simulation Models: A Comparative Study. New York: John Wiley \& Sons, 1975.

16. Coase R. Firma, ryinok i pravo. Per. s angl. M.: Novoe izdatelstvo, 2007. S. 7-35. [In Russian].

17. Coase R. H. The nature of the firm. Economics. 1937. V. 4 (5).

18. Cobham A., Janskэ P. Measuring Misalignment: The Location of US Multinationals' Economic Activity versus the Location of their Profits. Development Policy Review. 2017. No. 37 (1). P. 91-110.

19. Commons R. J. Institutional Economics. American Economic Review. 1931. Vol. 21. P. 648-657.

20. Crawford S., Ostrom E. A Grammar of Institutions. American Political Science Review. 1995. Vol. 89. №3. September.

21. Currency Composition of Official Foreign Exchange Reserves (COFER). IMF, 03.31.2020. URL: https: / / data.imf.org / ?sk=E6A5F467-C14B-4AA8-9F6D5A09EC4E62A4

22. Dunning J. H. Explaining changing patterns of international production: in defence of the electric theory. Oxford bulletin of economics and statistics. 1979. №41 (4). P. 269-295.

23. Filipenko A. S., Dziuba P. V. Teoriia mizhnarodnoho biznesu: vid narodzhennia do sohodennia. Aktualni problemy mizhnarodnykh vidnosyn. 2019. Vypusk 138. S. 168. [In Ukraianian].

24. Finansovi rynky Pivdenno-Skhidnoi Azii: dyversyfikatsiina panorama: monohrafiia / O. M. Halenko, Ya. M. Stoliarchuk, A. V. Shlapak. - K.: Feniks, 2016. [In Ukrainian].

25. Friedman M. The Methodology of Positive Economics. In: M. Friedman. Essays in Positive Economics. Chicago, 1958.

26. Ghoshal S., Bartlett C. A. The multinational corporation as an interorganizational network. Academy of management review. 1990. No. 15. P. 603626.

27. Global financial assets to touch USD 317 trillion by 2020. URL: https: / / www.moneycontrol.com/news/world/-1203105.html

28. Global Wealth 2020: The Future of Wealth Management. 20th Edition. A CEO Agenda. Boston Consulting Group, June 2020.

29. Globalnoe ekonomicheskoe razvitie: tendentsii, asimmetrii, regulirovanie: monografiya / D. Lukyanenko, V. Kolesov, A. Kolot, Ya. Stolyarchuk i dr.; pod nauch. red. D. Lukyanenka i A. Poruchnika. - K.: KNEU, 2013. [In Russian].

30. Harris F. W. How Many Parts to Make at Once. Operations Research. 1990. Vol. 38. №6. P. 947-950.

31. Henry J. S. Taxing Tax Havens. Foreign Affairs, April 122016.

32. Heyfets B. A. Ofshornyie finansovyie seti $\mathrm{v}$ mirovoy ekonomike Geografiya mirovogo razvitiya. Vyipusk 2: Sbornik nauchnyih trudov / Pod red. L. M. Sintserova. M.: Tovarischestvo nauchnyih izdaniy KMK, 2010. S. 84. [In Russian]. 
33. Heyfets B. A. Ofshornyie yurisdiktsii v globalnoy i natsionalnoy ekonomike: monografiya. M: ZAO «Izdatelstvo «Ekonomika», 2008. [In Russian].

34. Hlobalnyi rynok intelektualnoi vlasnosti: monohrafiia / O. Yu. Bilenkyi, Ya. M. Stoliarchuk, O. M. Halenko, V. M. Stoliarchuk. Kyiv: Feniks, 2016. S. 47. [In Ukrainian].

35. Houpt J. International activities of US banks and US banking markets. Federal Reserve Bulletin, September 1999. P. 599-615.

36. Hymer S. The International Operations of National Firms: A Study of Direct Investment. MIT Press, 1976.

37. Insured U.S.-Chartered Commercial Banks that have consolidated assets of USD 300 million or more, ranked by consolidated assets as of March 31, 2020. Federal Reserve. URL: https://www.federalreserve.gov/releases/lbr / current/lrg_bnk_lst.pdf

38. Istoriia ekonomichnykh uchen: Pidruchnyk / [V. D. Bazylevych, T. V. Haidai, N. I. Hrazhevska ta in.]; za red. V. D. Bazylevycha. K.: Znannia, 2004. S. 520. [In Ukrainian].

39. Izhevskyi P. H. Teoretychni zasady formuvannia biznes-merezh na bazi teorii transaktsiinykh vytrat. Hlobalni ta natsionalni problemy ekonomiky. 2016. Vypusk 12. 258 p.. [In Ukrainian].

40. Kindleberger C. P. American Business Abroad: Six Lectures on Direct Investment. New Haven: Yale University Press, 1969.

41. Largest asset management companies worldwide as of March 2019, by managed assets (in trillion U.S. dollars). Statista. The Statistics Portal. URL: https: / / www.statista.com / statistics / 431790/leading-asset-managementcompanies-worldwide-by-assets /

42. Leading major financial assets worldwide as of December 2019, by average daily trading volume (in billion U.S. dollars). Statista. The Statistic Portal. URL: https: / / www.statista.com / statistics / 625422/daily-trading-volumes-of-majorfinancial-assets-worldwide/

43. Libman A. International Experience of Tax Optimization - The Role of Tax Competition and Offshores in Global Economy. Munich Personal RePEc Archive. MPRA Paper No. 17042, 2004.

44. Lipton D. Shining a Light. Bringing money out of the shadows means improving governance. Finance \& Development, September 2019.

45. Makarov V. V., Makarova Yu. S. Organizatsiya offshornogo predprinimatelstva v usloviyah globalizatsii ekonomiki. SPb., 2001. S. 23. [In Russian].

46. Marshall A. Printsipyi ekonomicheskoy nauki: V 3 t.: Per. s angl. M.: Progress, 1993. [In Russian].

47. Mirovaya ekonomika: globalnyie tendentsii za 100 let / Pod red. chlenakorrespondenta RAN I. S. Koroleva. M.: Yurist', 2003. [In Russian].

48. Mitchell U. Ekonomicheskie tsiklyi: Problema i ee postanovka. M. - L.: Gosizdat, 1930. [In Russian].

49. Mizhnarodnyi dosvid rehuliuvannia rynku Foreks. Financial and Economic Analysis Office in the VRU. Kyiv, 2017. [In Ukrainian].

50. Mudrak N. O. Natsionalni mehanizmi borotbi $z$ uhilennyam vid opodatkuvannya cherez ofshorni yurisdiktsiyi v krayinah OESR. Naukoviy visnik 
Uzhgorodskogo natsionalnogo universitetu. Seriya Mizhnarodni ekonomichni vidnosini ta svitove gospodarstvo. 2019. Vipusk 25, chastina 2. C. 5-11. [In Ukrainian].

51. Number of high net worth individuals worldwide from 2010 to 2018, by region (in millions). Statista. The Statistics Portal. URL: https: / www.statista.com / statistics / 263488 / millionaires-worldwide-by-region /

52. Penrose E. T. The Theory of the Growth of the Firm. Oxford: Basil Blackwell, 1963.

53. Pidchosa O. V. Formuvannia teorii transnatsionalnykh korporatsii: bazys ta tendentsii rozvytku. Aktualni problemy mizhnarodnykh vidnosyn. 2010. Vypusk 94. (Chastyna II). S. 257-265. [In Ukrainian].

54. Pigu A. Ekonomicheskaya teoriya blagosostoyaniya. T. 2. M., 1985. [In Russian]..

55. Porter M. E. Competitive Strategy: Techniques for Analyzing Industries and Competitors. New York: The Free Press, 1980.

56. Pryroda firmy: pokhodzhennia, evoliutsiia i rozvytok / za red. O. I. Viliamsona, S. Dzh. Vintera. Per. Z anhl. A. V. Kulykova. K.: A.S.K., 2002. [In Ukrainian].

57. Puzakova E. P., Shepel T. S. Soderzhatelnaya struktura protsessa ofshorizatsii mirovoy ekonomiki s pozitsiy urovnevogo podhoda. Natsionalnyie interesyi: prioritetyi i bezopasnost. 2015. No. 10 (295). S. 57-64. [In Russian].

58. Redziuk E. V. OfshorizatsIya svItovoyi ekonomiki: perspektivi dlya Ukrayini i svitu. Visnik Asotsiatsiyi doktoriv filosofiyi Ukrayini. 2015. No. 1. URL: http: / / aphd.ua/publication-34/ [In Ukrainian].

59. Renminbi deposits. Hong Kong Financial Authority. URL: https: / / www.hkma.gov.hk / eng / data-publications-and-research / data-andstatistics / monthly-statistical-bulletin / table /

60. Rohach O. Teorii mizhnarodnoho biznesu. K.: VPTs «Kyivskyi universytet», 2018. S. 549-582. [In Ukraianian].

61. Rugman A. M., Verbeke A. Extending the theory of the multinational enterprise: internalization and strategic management perspective. Journal of International Business Studies. 2003. No. 34. P. 125-137.

62. Sam Ro. Here's what the USD 294 trillion market of global financial assets looks like. Business Insider, February 11, 2015. URL: http: / / www.businessinsider.com / global-financial-assets-2015-2\#ixzz3g59m5Fic

63. Shewhart W. A. Economic control of quality of manufactured product. New York: D. Van Nostrand Company, 1931.

64. Stapran D. A. K voprosu o teorii i praktike (aut)sorsinga. Rossiyskoe predprinimatelstvo. 2016. T. 17. No. 7. S. 847. [In Russian].

65. Stopfor J. M., Dunning J. H., Haberich K. The world directory of international enterprises. 1980.

66. Summary of foreign claims (immediate counterparty basis), by nationality of reporting bank. Amounts outstanding / Stocks at end December 2019, in billions of US dollars. Bank for International Settlements. URL: https: / / stats.bis.org / statx / srs / table /b2?m=S\&f=pdf

67. Taylor F. W. The Principles of Scientific Management. New York: Harper \& Brothers. 1911. 
68. The New Dynamics of Financial Globalization. McKinsey Global Institute. August 2017.

69. The Price of Offshore Revisited. New Estimates for Missing Global Private. Wealth, Income, Inequality, and Lost Taxes. Tax Justice Network, July 2012.

70. These five countries are conduits for the world's biggest tax havens. The Conversation, July 24, 2017. URL: https://theconversation.com/these-fivecountries-are-conduits-for-the-worlds-biggest-tax-havens-79555

71. Track RMB internationalization on the Bloomberg Terminal. A Bloomberg Professional Services Offering. URL: https://data.bloomberglp.com/ professional/sites / 10/RMB-Internationalization.pdf

72. Tymoshenkov I. V., Nashchekina O. M. Transaktsiini vytraty opodatkuvannia yak skladova mizhnarodnoi konkurentospromozhnosti krainy. Ekonomichna teoriia ta pravo. 2017. No. 4. S. 39. [In Ukrainian].

73. Ultra high-net-worth individual. URL: https://en.wikipedia.org/ wiki/Ultra_high-net-worth_individual

74. Value of assets under management worldwide in selected years from 2002 to 2017 (in trillion U.S. dollars). Statista. The Statistics Portal. URL: https: / / www.statista.com/statistics /323928 / global-assets-under-management/

75. Veblen T. The Theory of Business Enterprise, 1904.

76. Vernon R. International Investment and International Trade in the Product Cycle. Quarterly Journal of Economics. 1966. No. 80. P. 190-207.

77. Worldwide wealth distribution by net worth of individuals 2018. Statista. The Statistics Portal. URL: https://www.statista.com/statistics / 203930/globalwealth-distribution-by-net-worth

78. Zablotskyi A. V. Ofshorynh na svitovomu rynku posluh: teoriia ta perspektyvy rozvytku. Aktualni problemy mizhnarodnykh vidnosyn. 2012. Vyp. 110 (1). S. 15-21. [In Ukrainian].

79. Zorome A. Concept of offshore financial centers: In search of an operational definition. IMF Working Papers. WP /07/87. April 2007.

80. Zucman G. How Corporations and the Wealthy Evade Taxes. New York Times, November 102017.

The article was received by the Editorial Board on April 06, 2021. 